\title{
Phantasmagorias of Power: Hebbel's Drama Gyges und sein Ring
}

\author{
Albrecht Koschorke
}

1

Friedrich Hebbel wrote his play Gyges und sein Ring between 1853 and 1854 , hence only a few years after the March Revolution of 1848 . He prefaced the play with a brief note that he apparently found necessary for the reader's orientation. "The action," he indicated, "is prehistorical and mythic; it takes place within a temporal span of twice twenty-four hours." This sentence offers information about the temporal dimensions of Gyges from two perspectives, although the sentence's parts, aligned in peaceful parataxis, stand in nearly comical incongruity with each other.

On the one hand, there are the technical specifications of the length of action: "twice twenty-four hours" tied to a tacit concession that Hebbel's most classical play in this way lacks one of the basic requirements of classical drama, temporal unity. This fact is not trivial, for the catastrophe of Gyges takes place in, as it were, the temporal fold between the two days of dramatic action. And it does so in a locus removed from the audience's view: the royal bed-chamber. However great the nocturnal intrigue's theatrical potential-a peculiar ménage à trois involving a loving king, his naked wife, and a voyeur

\footnotetext{
${ }^{1}$ All citations of Friedrich Hebbel's play Gyges und sein Ring refer to Friedrich Hebbel, Gyges und sein Ring. Eine Tragödie in fünf Akten (Stuttgart: Reclam, 1997), here (4). All English translations of this text and of all other quotations except where otherwise noted are by Joel Golb.
} 
ordered to the scene-it nevertheless takes place beyond the stage. In this manner the theme of visibility and invisibility that determines the play's action is mirrored on the level of its performance.

Where the days are measured here in miniature, almost chronometrically, the sentence's first part occupies a completely different temporal order. Hebbel's dramaturgical note locates the play-in which thresholds, transition-points, borders, and the transgression of them are hugely important-before history, hence in a sphere outside any positively measurable time. One might even say that he wishes to have the action unfold on the edge of time. According to the author's own interpretation, what needs forty-eight hours to reach its tragic end is a myth to which no assignment of date applies.

In this use of the attribute "mythic," Hebbel is to a certain degree in harmony with the antique transmitters of his dramatic material. ${ }^{2}$ The most important classical sources that Hebbel could have used are Plato and Herodotus. In the second book of the Republic, Plato has one of the interlocutors introduce the example of the shepherd Gyges, who lures the wife of the Lydian king Kandaules into adultery with the help of a magic ring and then kills the king to gain possession of wife and crown. Through this violence, Gyges becomes the "ancestor of the Lydians." Herodotus says nothing about a ring and has King Kandaules himself take the initiative and force his bodyguard Gyges to hide as a voyeur in the royal bedroom; the queen, however, learns of this dishonorable action and forces Gyges to assassinate her husband. ${ }^{4}$ Kandaules, remarks Herodotus, was the last Lydian ruler who could trace his ancestry back to the half-god Heracles: with his death, the Heracleidan race was extinguished. ${ }^{5}$

Antiquity thus situates the episode at precisely the point where myth and history touch: Kandaules, the last descendent of the mythic hero Heracles, dies as a result of an intrigue; wife and office fall to Gyges, a shepherd or bodyguard without pedigree mentioned at the

\footnotetext{
${ }^{2}$ It is worth noting that he learned of the story from an official working in the library of the Vienna police; he appears to have visited the reading room of the Ministry of Police to learn more from Pierers Universallexikon-a striking example of cooperation between poetry and the police. Friedrich Hebbel, Werke, ed. Gerhard Fricke, vol. 2 (München: Hanser, 1964) 695.

${ }^{3}$ Plato, "Republic," Collected Dialogues, ed. Edith Hamilton and Huntigton Cairns (New York: Pantheon Books, 1961) 359.

"Herodotus, The History, trans. David Grene (Chicago, London: UP of Chicago, 1987) $36-39$.

${ }^{5}$ Herodotus 36
} 
start of Herodotus's historical account of Lydia. With closer scrutiny, one sees that Hebbel follows the antique model in this respect as well: the drama's opening scene already contradicts the assertion of inherent obedience to mythic temporal form, the ruling king announcing his determination to break with mythological tradition. He autocratically suspends rituals practiced from time immemorial, elevating himself over his people-they still cling to superstitionwith the intent of leading them to enlightenment. Consequently, Kandaules is here represented as a figure on a threshold, seeking an escape from mythic bonds. ${ }^{6}$ But precisely through this reckless and remarkably blind will to enlightenment, the last of the Heracleidans conjures up his own destruction. That the fate of this enlightener bears traces of an apparently mythical inescapability counts as one of the paradoxes of Hebbel's play: a paradox virulently manifest on several of its levels. ${ }^{7}$

2

The tragedy begins with a classical act of investiture. The friends "Kandaules and Gyges appear on stage," note the stage directions. "Kandaules buckles on his sword," the old slave "Thoas follows with the diadem." ${ }^{8}$ But it is the false diadem. For the festival of Heracles, Thoas wishes his master to wear the crown bequeathed by his illustrious ancestor and worn by all kings since then (Gyges 1.13-49). Kandaules, however, has new insignias forged. He no longer accepts

\footnotetext{
${ }^{6}$ Alexandra Tischel [Tragödie der Geschlechter. Studien zur Dramatik Friedrich Hebbels (Freiburg: Rombach, 2002) 109-11] has already argued, convincingly, that Gyges is himself located on a threshold separating barbarism from Hellenism: "Hebbel's 'mythic' tragedy begins . . . at a moment in which the Greek-barbarian differential model does not yet stamp the "classical" Greeks (among whom Herodotus can be counted) but rather is nascently present in the 'archaic' pre-phase" (109).

${ }^{7}$ Hebbel's guarantor Herodotus, the founding father of historiography, himself moves along such a threshold. For his part Hebbel's concept of "pantragism" derives its life from a move away from nineteenth-century historicism into a pre-historical idea of fate. See Heinz Schlaffer, "Friedrich Hebbels tragischer Historismus," Studien zum ästhetischen Historismus, ed. Hannelore Schlaffer and Heinz Schlaffer (Frankfurt am Main: Suhrkamp, 1975) 121-39, and, commenting on that article, Ludger Lütkehaus, Dialektik der Aufklärung. Hebbels 'Gyges und sein Ring' (Heidelberg: C. Winter, 1983) 8. In relation to Gyges, Hebbel expresses the hope "not to have missed the point of intersection where antique and modern atmospheres converge." Friedrich Hebbel, "Letter to Friedrich von Uechtritz, 14 Dec. 1854," Werke, ed. G. Fricke, vol. 2 (München: Hanser, 1964) 697.

${ }^{8} \mathrm{Hebbel}$, Gyges und sein Ring 5.
} 
Shining merely through bequeathed adornment, Being valued the way stamped coins are valued, Which no one weighs, and sharing with statues That stand in consecrated temple crannies Base inviolability. . . .

Bloß durch den angestammten Schmuck zu glänzen, $\mathrm{Zu}$ gelten, wie geprägte Münzen gelten,

Die keiner wägt, und mit den Statuen,

Die in geweihten Tempelnischen stehn,

Die schnöde Unverletzlichkeit zu teilen. . . .

(Gyges 1.56-60)

Rule, insists Kandaules, should not rest on antiquarian foundations. Heracles's crown is too large for him, Heracles's sword too unwieldy, hence he has ordered new versions of both-versions that are usable in a smaller, "humanly narrow space" (Gyges 1.80). Something caricatured, inappropriately civilized, clings to the Lydian king so manifestly endowed with less physical strength than his ancestors: "[It] exhausts all my strength in its drawing" is his own reference to the old sword (385). He does not participate in the jousting; despite sweeping prognostications he has to suffer one defeat after another; and in the end he is killed in combat by the very same sword-exchanged with Gyges, along with other objects, in return for the restituted ring (Gyges 2.875) - whose human measure and practicality he praised at the start. But in fact, it would be unfair to judge Kandaules exclusively in terms of the old typology of the incompetent ruler as weakling and ladies' man, his tragedy reduced to banefully erotic pride of possession. For along with displaying such negative qualities, he reveals himself as a visionary who intends to ground his government in a new and modern political economy:

THOAS arrives with the new crown.

KANDAULES. Very good!

Places the diadem on his head.

It fits! And everything my kingdom offers

In pearls and gems from mountain shafts

And depths of the sea,

No more, no less, is unified here:

The jewel absent from our land

However beautiful, is strictly banished,

Though to be sure I'd also find a place

For one only to be discovered in a hundred years. 
THOAS kommt mit dem neuen Schmuck. Kandaules. So ist es recht! Er setzt das Diadem auf.

Das sitzt! Und alles, was mein Königreich

Im Schacht der Berge und im Grund des Meeres

An Perlen und Kleinodien nur liefert,

Nicht mehr, noch weniger, ist hier vereint:

Der Edelstein, den man bei uns nicht findet,

Und wär' er noch so schön, ist streng verbannt,

Doch freilich ließ ich auch für den noch Platz,

Den man in hundert Jahren erst entdeckt.

(Gyges 1.61-69)

Instead of legitimating his kingdom through descent from a hero, Kandaules finds such legitimation in Lydia's fabulous wealth, already proverbial long before the reign, later on, of Gyges's descendent Croesus. ${ }^{9}$ The crown is meant not only to symbolize this wealth but to bear it materially in the form of "pearls and gems." ${ }^{10}$ The genealogical principle is replaced by a territorial principle: alone those jewels obtained from Lydian soil are allowed to adorn the ruler's head. And where genealogy always points back toward a terminated past, the political economy Kandaules has in mind is dynamic and open to the future: room is left on the new-forged crown for later discoveries of precious stones, in other words for the growth of managed wealth.

According to Herodotus, coinage was invented in Lydia. ${ }^{11}$ The first book of the History repeatedly addresses the connection between power, accumulation of wealth, and bureaucracy. ${ }^{12}$ Other antique authors also tie the Gyges-legend to the emergence of a money

\footnotetext{
${ }^{9}$ For this and the following see Marc Shell, "'The Ring of Gyges," The Economy of Literature (Baltimore, London: Johns Hopkins UP, 1978) 15.

${ }^{10}$ Andrea Stumpf, Literarische Genealogien. Untersuchungen zum Werk Friedrich Hebbels (Würzburg: Königshausen \& Neumann, 1997) 113, observes that "a complex displacement or dissolving of the political symbolism thus occurs: the introduction of the body that is too weak and no longer occupies a field of sovereign representation; the shift from metaphor (the sword for strength) to metonymy (the stones from various part of the country); the transition from pedigree to wealth and thus a turn from the nonexchangeable (inheritance, blood) to a value whose measure is, precisely, exchange. ... In a specific sense, political power is here being negotiated: as entry into the market, into circulation."

${ }^{~ " H e r o d o t u s ~ 78: ~ " T h e ~ L y d i a n s ~[. . .] ~ a r e ~ f i r s t ~ o f ~ t h e ~ m e n ~ o f ~ w h o m ~ w e ~ k n o w ~ t o ~ c u t ~ a n d ~}$ use a currency of gold and of silver. They were also the first to become shopkeepers."

${ }^{12}$ See Shell 14.
} 
economy. ${ }^{13}$ This is the case for Hebbel as well, his drama extensively exploring the motifs of money, payment, treasure, exchange, and circulation. To be sure, it does so with the difference that Hebbel locates the alliance between money and rule in the figure of Kandaules, which means on the loser's side in the power struggle. Kandaules is blind to his faithful slave Thoas's warning that the rules of an exchange economy do not support, but rather endanger, the position of an absolute ruler. In a speech that, measured against his status, is inappropriately long, Thoas juxtaposes the old and new insignias, defining in the process the contrast between traditional and "modern" forms of rule:

THOAS. My lord, it's not without a shudder

That I touch this diadem, and never

Have I yet grasped this sword by its handle-

A sword all the Heracleidans have at some time swung.

But I consider your new crown entirely

Like any other thing that gleams and glitters,

And that one owns because one can pay for it.

I here do not need to think of Haphaestos

Who forged the weapons of divine Achilles-

And this in the fire he also used

To harden the lightening bolt belonging to Zeus.

...

For I know the man who produced the sword

And he who saw to the diadem's construction.

THOAS. O Herr, nicht ohne einen Schauder

Berühre ich dies Diadem, und nie

Hab ich dies Schwert am Griff noch angefaßt,

Das alle Herakliden einmal schwangen.

Doch deinen neuen Schmuck betracht ich ganz,

${ }_{15}^{15}$ Shell 12: "Whether or not Gyges or his descendant was in fact the first man to mint coins, he was associated in the mind of the Greeks with minting. Like Midas, his neighbor who turned all things into gold with a touch, Gyges turned all things into gold by his ability to purchase them with gold minted into coins.

As coinage was associated with the Lydians, so too was political tyranny. . . . Many Greeks believed that Gyges was the first tyrant, and often associated him with tyranny; he was the archetypal tyrant as he was the archetypal minter. Indeed, the frequent association of tyranny and minting with one man suggests that they may be mutually reinforcing and interdependent.

... Tales of Gyges associate him with founding a tyranny in Lydia and with a power of being able to transform visibles into invisibles and invisibles into visibles. This power $\ldots$ is associated with new economic and political forms that shattered the previous world and its culture." 


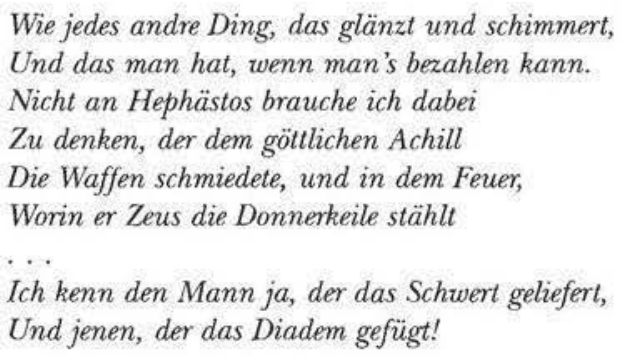

(Gyges 1.21-36)

Instead of simply being satisfied with symbolic value such as that furnished by medals "that no one weighs," Kandaules hopes to see himself mirrored in the monetary wealth of his land. But can royal insignias actually be purchased? Do they bear being produced and exchanged for money? How can the sacral nature of the kingdom be preserved if the production of its symbols is open for scrutiny in this manner, bereft of secrets? Kandaules rebels against the idea of his natural body being literally oppressed by the burden of autocratic representation: he tries to mold its symbolic presence to his empirical manifestation. But through this harmonizing effort, he actually destroys his kingdom's symbolic sphere; for the sake of his natural body, he renounces the corporative pact he has made with his people. The physical body has different lines of demarcation from those of corporative existence. Namely, in the eyes of the king's subjects, his insignias and body form a metonymic unit that must not be torn apart. In Thoas's words:

Your head and this band, for them they are

-Just trust your servant- two halves of a whole.

The same with your arm and this sword.

Dein Haupt und dieser Reif, das sind für sie, Trau deinem Knecht, zwei Hälften eines Ganzen, Und ebenso dein Arm und dieses Schwert.

(Gyges 1.43-45)

The people are "so foolish or pious" (Gyges 1.42) that they see a sacrilege in Kandaules's capricious innovation. They have "indignation" in mind, and a "new choice of kings" (Gyges 2.560-61). Kandaules' mockery of the "base inviolability" guaranteed him by his symbols of power (Gyges 1.60), his new investiture's shift of focus from the king's ritual presence to his individual body, turn directly against the Lydian king himself. For with Gyges, emerging triumphant from 
the ceremonial games, an aspirant to the throne appears on the scene who is far more convincing in this field of action. After the idea of exchange is released into the world, hardly any time passes before its demythologizing —or more generally put, desymbolizing-power rebounds on its author.

\section{3}

Also, the ring Gyges bestows on the Lydian ruler can be understood as one of the drama's negotiatory insignias. It is expressly referred to as a "royal ring" (Gyges 1.130, 149). Where Plato's Gyges is a graverobber, Hebbel civilizes him to the point of having him fall into a grave-ditch while fleeing from robbers: an accident that allows him to discover the unearthed ring, its magic capacity to endow invisibility then saving his life. Whether robbed from the grave or not, the ring stems from the world of the dead. Gyges holds his breath in the dusty ditch "in order not to breath in unwillingly / those who are like me, perhaps my fathers" (Gyges 1.173-74). To this extent the ring produces a bridge to the forefathers, which means also to the same mythological sphere from which Kandaules wishes to free himself. As an ornament stemming from Lydian soil, it is also tied to the new, territorial definition of his kingdom: in antique law discovered treasure was the sovereign's property. ${ }^{14}$

To be able to see without being seen is a divine attribute. In the human world it characterizes the tyrant, who knows how to hide himself, to impose sanctions on the free view of his face while having eyes and ears everywhere himself. ${ }^{15}$ In Hebbel's play, King Kandaules makes use of the wonderful ring in a twofold and apparently highly contradictory manner. On the one hand, he mixes anonymously among his subjects and plays the "herm-watchman" and "boundarypost king," as his opponents scornfully name him (Gyges 1.358-59), thus elevating himself once again to lord of the threshold: the threshold of houses, as well as that threshold located between

\footnotetext{
${ }^{14}$ Shell 28.

${ }^{15}$ As transmitted by Herodotus, the history of the Median tyrant Deiokes is paradigmatic in this context. Deiokes, we are informed, barricaded himself in a fortress made up of concentric ringed walls, introduced courtly custom, rendered himself both unseen to his vassals and all-seeing through a system of spies, and transformed the legislative process into something non-public and bureaucratic (Herodotus 79).
} 
kingdom and tyranny. ${ }^{16}$ But on the other hand, he concedes the divine and royal privilege of invisibility to another man, his friend Gyges, while he declares himself ready to figure as an object of observation-and this in the most intimate conceivable locus, the bed of royal matrimony. What minimizes the apparent contradiction is the fact that Kandaules lays claim to sovereignty in both roles, the role of observer and that of observed. In the first case, he can be an omniscient and thus absolute ruler; in the second case, he intends to be confirmed in the eyes of an outsider as possessor of the most beautiful of all women - to be admired and envied as erotic sovereign.

When handing over his present, Gyges declares that the ring cannot be bought for an entire kingdom (Gyges 1.137). Hence the magic jewel itself does not belong to any circulatory process for goods or money. Through the bedroom intrigue arranged by Kandaules, it nonetheless becomes a circulatory medium: the medium for the circulation of desire, playing itself out in the field of the natural body. In exchanging the ring, both friends render Rhodope, the eternally veiled queen, into an object of exchange. ${ }^{17}$ And as is the case with the insignias of Kandaules's dominion, crown and sword, he cannot control the dynamic of his initiated exchange. In the end, he has not only furnished his friend with Rhodope's sight, but lost her as a wife, who now sets about allying herself with his rival, against him and his life.

After the casting aside of the old symbols of power, the ring's exchange represents a second gesture of sovereignty-one that goes

\footnotetext{
${ }^{16}$ Compare the dispute between Kandaules and Rhodope over this magic "bugging" (Gyges 1.398). For Rhodope, the ring is a relic from a mythic age "when gods and men still walked together / and exchanged love tokens" (Gyges 1.424-25). She indicates that whoever uses "things that can shatter / The world" (Gyges 1.421-22) is guilty of hubris, thus drawing the gods' revenge on his head. Her prophecy shows itself to be true at the drama's end. Hence through acceptance of the ring, Kandaules the thresholdtransgressor falls under the spell of the same myth whose legitimacy he hopes to negate.

${ }^{17}$ Andrea Stumpf's pointed analysis, underscoring the "central movement" of Hebbel's drama's as "the circulation of the ring - as a symbol of 'male strength' it follows a logic of phallic circulation to the effect that whoever has it/her does not have her/it. Hence, whoever has the ring does not have the woman and inversely. The acts of exchange, in any case, proceed in this manner, and exchange is necessary for just this reason: Kandaules only has the woman (in this specific sense) when he gives Gyges the ring and with it the possibility of seeing the woman; but in doing so he also gives her away. And Gyges now has the ring, but not the woman whom he wants just then; he relinquishes the ring, gains the woman, whom he nevertheless does not gain, and so forth" (123). On the ring's phallic attributes, see also Lütkehaus 32.
} 
awry and culminates in the king's divestiture. The reasons he offers for enticing his hunting comrade into the nocturnal plot are related to the argument with which he justifies the procurement of contemporary insignias. Kandaules no longer wishes to keep his royal possessions hidden. On the one hand, he plans to coin his medals, which have not been passing from hand to hand, hence to transform them into movable capital (Gyges 1.57-61); on the other hand, he compares his wife, who insists on chaste reclusion, with a secret treasure whose flaw consists of not being displayable, hence capable of generating acknowledgment. "Who believes," he complains, "in pearls in a closed hand?" (Gyges 1.518). Hoarded treasures have no market value; for this reason they cannot satisfy the pride of their possessor, who needs a "witness," in other words recognition by a third party (Gyges 1.531). Hence, in a certain manner Kandaules has to bring his wife to the market in order to find his desire confirmedor indeed even sparked-by the desire of another:

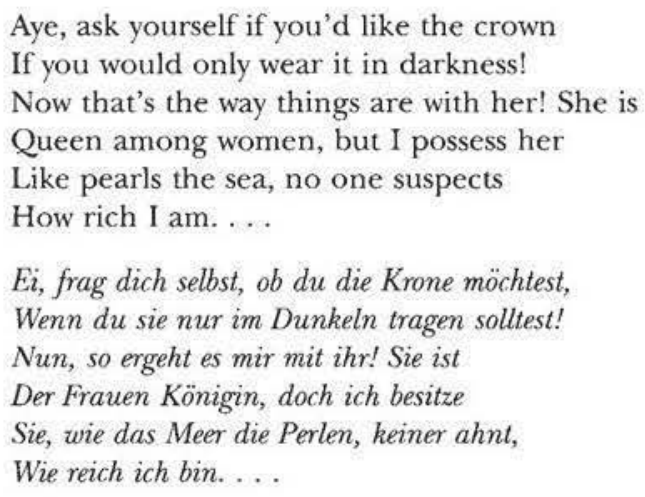

(Gyges 1.540-45)

Even as an erotic sovereign, the king desires to replace intrinsic value with exchange value. As Rhodope herself suspects at one point, the only lovable woman for Kandaules is the woman who is shared or exchanged..$^{18}$ Kandaules invites his friend to participate in a homosocial pact in which the men are partners in exchange and the women

\footnotetext{
${ }^{\text {tx }}$ Compare Rhodope's speech (Gyges 1074-78):

$\mathrm{I}$ always worried

There was more pride in ownership than love

In the feeling binding you to me,

And that your inclination needs others' envy

In order not to fully disappear!
} 
objects of a mimetic desire from whose binding structure they are nonetheless excluded. Kandaules encapsulates this mechanism in an economically pregnant formula:

For what ties one man with another, Is not present for the woman. . . .

Denn, was den Mann mit einem Mann verbindet, Ist für das Weib nicht da. . . .

(Gyges 3.1086-87)

I will not succumb to the temptation to explore this triangular constellation for its mimetic dynamic of desire in the sense of René Girard. ${ }^{19}$ I also wish to circumvent the "The King Seeks a Friend" story-notorious in German literature at least since Schiller's Don Carlos. Our concern in this context is the king's double desertion of his role: both as king and husband, he abandons his prominent place in the fixed symbolic order in order to win that place back in the view of the others-following Lacan, within the realm of the imaginary. ${ }^{20}$ In the end, this is a futile and deadly undertaking.

\section{4}

Hebbel and then Hebbel researchers had considerable trouble bridging the gulf between his play's relatively minor intrigue and its enormous tragic effect. Kandaules is hardly a tragic hero in the strict sense. He acts without thinking and makes mistakes in his private life that have fatal consequences-nothing more. Hebbel himself acknowledged the difficulty of sufficiently motivating Rhodope's reaction

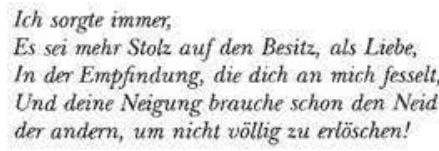

${ }^{19}$ René Girard, Mensonge romantique et vérité romanesque (Paris: B. Grasset, 1961) and René Girard, La violence et le sacré (Paris: B. Grasset, 1972).

${ }^{20}$ On the other side of the sexual order, the wish for erotic possession of the woman via the detour of a homosexual-imaginary structure, i.e. in the mirror of the friend's desire, destroys the woman's imaginary self-relation: she covers over the mirror (Gyges 3.892 ), tosses away the veil that Kandaules has described as "a piece of yourself" (Gyges 3.991 ), and allows the hour of the morning to slip away "In which you, as you so sweetly put it, / Observe your inner self" (Gyges 3.976-77). It is part of the logic of such a lost self-relation that in the end Rhodope stabs herself to death in the temple of virginal Hestia; see in this regard Lütkehaus 38 and Stumpf 119. 
to the nocturnal voyeuristic scene. Rather expediently, he moves her homeland to India, where especially strict rules of modesty are meant to predominate..$^{21}$ Still, that the unauthorized sight of an undressing woman represented a mortal crime was most likely implausible even in the framework of a mid-nineteenth-century German theater audience's moral standards. Let us here note that within the dramatic action, the precipitous ascent and guilty complicity of Gyges only make sense when he regains the characteristics of the political and sexual aggressor manifest in the antique sources. In actuality, even Hebbel's process of "sensitization, interiorization, and refinement of the original material," as the editors of the Werkausgabe choose to put it, ${ }^{22}$ offers hints that the "official" depiction of the voyeuristic scene covers up a cruder reading of the nocturnal events. It is the case that Gyges comes close enough to the desired queen to steal a diamond from her neck (characteristically, he returns it not to her but to her spouse (Gyges 2.878); less criminologically than emblematically, this might serve as evidence that he has shared Kandaules's hidden treasure. Face to face with Rhodope, Gyges compares himself to a youth who "Clutches at a wonderful bird / And crushes it"; he blames himself for having "destroyed / the jewel of this world" (Gyges 4.141924). Within topical tradition, these are of course standard paraphrases for defloration or at least sexual injury to the enclosed female zone. ${ }^{28}$

But at this point, we might possibly agree that extracting sexual secrets from the text which are hidden from its surface, thanks to our greater knowledge, is not ultimately very useful. At least when it comes to the play's positive manifestation, a peculiar disparity is unmistakable between the dramatic action and the dramatics of the drama itself. This disparity cannot be overcome by an appellative recourse to the

\footnotetext{
${ }^{21}$ This is in contrast to Herodotus, who stresses the modesty of Lydian women and the taboo placed on the sight of naked royalty: see Lütkehaus 36 and Peter Michelsen, "Rhodopens Schleier. Betrachtungen zu Friedrich Hebbels 'Gyges und sein Ring," Festschrift für Klaus Ziegler, ed. Eckehard Catholy and Winfried Hellmann (Tübingen: M. Niemeyer, 1968) 267, where Rhodope's forced behavior is seen as reflecting an authorial intention of rendering what she has experienced into "a tragedy under all circumstances."

Hebbel's diary entry of 14 December 1853 sheds light on the queen's motivation: "Today the 1st act of Rhodope finished. Braun von Braunthal called my attention to Herodotus's old fable of Gyges, I looked it up and found that it indeed contained a tragedy. But the queen's motivation will be difficult." Friedrich Hebbel, Tagebrücher, ed. Karl Pörnbacher, vol. 3 (Munich: Deutscher Taschenbuch Verlag, 1984) 136.

${ }^{22}$ Hebbel, Werke 696.

${ }^{23}$ For similar speculation regarding Gyges's "trophy," see Stumpf 122.
} 
pathetic understanding of tragedy as a genre in vogue in the nineteenth century. In what is probably the most important recent study of Hebbel, Andrea Stumpf has formulated the disparity as follows:

The movements and driving forces manifest in Hebbel's texts do not obey this generic decree: an excited discourse, a language of wishing, an anomic pressure that from the start attack measured form and diction. In this manner Hebbel's plays offer a double possibility of reading: a fulfillment of classical criteria can be recognized; but at the same time all of that is undermined-there are holes in the motivation, holes in the action's coherence, an undirected form of activity. . . . 4

If this assessment is accurate, what, then, is the source of the text's unease? What causes the high excitation that exceeds the discourse's occasion? What renders the way the play's personae behave so eccentric and incalculable in face of a will to poetic form strictly centered on classicism? Making Hebbel's desire for a pre-Enlightenment, hence anachronistic, tragedy responsible for such forced qualities is insufficient. ${ }^{25}$ In any event this problem's scope extends beyond the limits of a Hebbel exegesis. It leads us toward the very basis of literary theory because it is here that the fundamental question of deployment is posed: the deployment of dramatic agents into a sequence of actions escalating into deadly struggle, but also of literature as a specific form for describing processes unfolding in the sphere of power. Drama is the literary genre for power-analysis, par excellence. This is also, and specifically, the case for Hebbel the dramatist, who shares with Nietzsche a special obsession with the phantasmagorical essence of power-an obsession placed under the sign of power's metaphysical groundlessness.

\footnotetext{
${ }^{24}$ Stumpf 127.

${ }^{25}$ Heinz Schlaffer thus wrote in the 1970s: "Hebbel's characters are tragic in the sense that their most prominent quality is an inclination towards the tragic. Golo's, Mariamne's, and Rhodope's will to the tragic appears to justify Hebbel's will to tragedy: what objections can be raised to tragedy when a drama's heroes expressly claim responsibility for it? But they are lacking the same motivation as does the form; the dilemma is not resolved, but simply displaced and-once the basis for the displacement is recognized-all the more clearly exposed. To be sure, a dilemma is present here that none of the newer efforts at tragedy has been able to avoid: When, as in modern times, the efficacy of historical-political power, on the one hand, represents itself in an abstract and impersonal manner; and, on the other hand, the individualfreed from precisely that efficacy and relegated to the private sphere-considers himself to be inclined towards freedom and reason; then the tragic principle, emerging from the tense unity of general "should" and individual "must," no longer has a locus" (133).
} 
In order to consider this more closely, a recapitulation may now be helpful. A ruler appears on the scene, opening Hebbel's drama by using his arbitrary authority to offer up his personal power, indeed his regime's legitimacy. His sovereign gesture announces a determination to emancipate himself from mythic origins, and with them from the world of the ancestors and the dead. The new insignias he chooses shift the focus of his rule's representation from the past to future-thus to uncertainty. As a countermotif, the ring now comes into play, its magic powers bound to the same mythic origins: as a "ring of the dead" (Gyges 5.1969), it has itself reached the world of the living from that of the ancestors. Although its own value is incalculable, this ring becomes the driving element in the complex exchange relations between the dramatis personae, thus fitting into the play's thoroughly modern exchange economy. Rhodope's assessment of her husband's deed is itself not free from a certain decisionism:

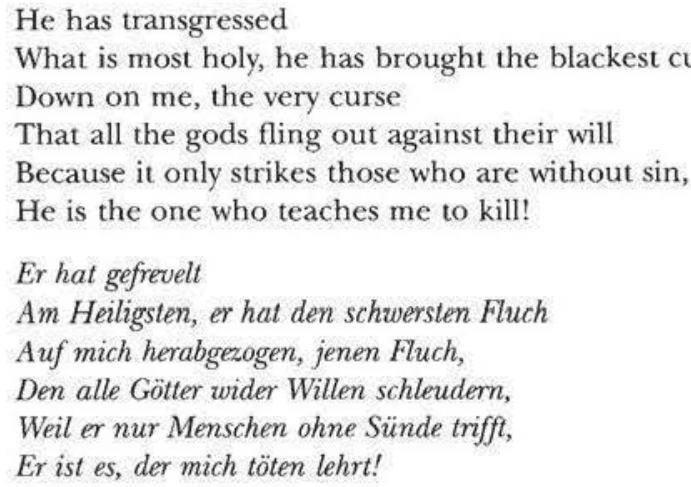

(Gyges 3.1224-29)

And her monologue at the start of the fourth act makes completely evident that the moral law of her homeland only becomes imperative through an act of sheer will:

The more I think about it, the less

I comprehend my husband. I already heard

In earliest youth that the soiled

Are not allowed to live, and if as a child

That made me shudder, I've now found the ground

For that law in my own breast:

She cannot live, nor does she want to!

Je mehr ich sinne, um so weniger

Begreif ich meinen Gatten. Hört' ich's doch 
In frühster Jugend schon, daß die Befleckte

Nicht leben darf, und wenn mich das als Kind

Durchschauert hat, jetzt habe ich den Grund

Für dies Gesetz in meiner Brust gefunden:

Sie kann nicht leben, und sie will's auch nicht!

(Gyges 4.1267-73)

The tragic energy of Gyges cannot be derived from the classical generic doctrine that conflicting norms determining the protagonists' behavior lead to a collision with iron necessity. On the contrary, the norms find themselves in a state of suspense, and thus divergent motivations and claims to validity face each other almost without connection. This dramatization of contingency defines the involuntary modernity of Hebbel's putatively mythic tragedy. This is not meant to suggest that pure chance determines the action's progress. Rather, Hebbel's problem in shaping his play involves a peculiar semantic overloading of every single sequence of action in that the behavior of the personae does not rest on immemorially a priori orders of value but has to bear the entire burden and affective expenditure of self-projection from moment to moment.

The first act annuls the order, puts a stop to the code. Everything now seems open, available for negotiation, decidable in one or another way. The levels of symbolic regulation and factual behavior are no longer separate, instead plunging into each other as it were; rather than meshing into a continuum of action, the individual actions spring forward in the shape of solitary presumptions from the nothingness of uncertain validity-principles. And because this is so, the individual efforts of the drama's agents, all of them circulating around the pole of power in dangerous proximity, are no longer calculable. Kandaules, who wishes to see his possession confirmed by releasing it for exchange and sharing it, finally loses everything. Gyges, defined as a hovering figure without identity through his role as a third party arriving on the scene, incites his own death through violation of the rules, constantly wishes to sacrifice himself, and nevertheless takes the king's place in the end. ${ }^{26}$ Rhodope, wounded

\footnotetext{
${ }^{26}$ Compare Claudia Pilling, Hebbels Dramen (Frankfurt am Main: P. Lang, 1998) 159 “Against his first intentions, Hebbel did not name the drama . . 'Rhodope' but chose the survivor as his titular hero, in contrast to the generic convention. Gyges, who demands the resolution of his 'tragic fate,' hence, who sees his destruction as reconciliation, who twice offers his sacrificial death, survives . . . as a modern hero without pathos. He lets himself be dissuaded from death; he always accepts the position of the other: Kandaules's modernity, Rhodope's archaicism, and Thoas's traditionalism."
} 
through her treatment as an exchangeable love-object, nevertheless promises herself to the victor of the tournament-combat as a prize, only to break the promise immediately by stabbing herself to death after the wedding ceremony.

All these linkages are located in a vacuum that is not only psychological but also symbolic. They are not reinsured by a valid code or binding metanarrative. Between deed and reaction, there is no collectively certified rule of juncture, no measure, hence no equivalence. This is the precise reason for the figures' incapacity to hold their own exertions within bounds: with the symbolic order no longer offering them protection, every turn of the action confronts them with an empty absolute. Translated into the cipher-language of tragedy, every speech act tends to become a life-and-death risk. In this respect Hebbel's play simulates antique tragedy, though not because his heroes subsume themselves to a higher order that is fatal to them, but rather because they have fallen out of it. Considered from this perspective, their action produces no tragic "meaning"; it is action unfolding in an empty space-an action only asserting necessity and order through its execution.

With the vanishing of the hierarchy of levels between steering code and individual action, a second difference, constitutive for the space of monarchic power, also vanishes: the difference between institutional rule and arbitrary authority. While legitimate rule is marked by a process of differentiating itself within itself and exercises power in the name of another, that of the law, power and law collapse tautologically into one as "right of might" with the simple application of force. Gyges und sein Ring does not play out this collapse of the symbolic codification of rule and naked power to the same degree as other plays of Hebbel such as Herodes und Mariamne and the Moloch fragment. But the logic of the conflict is nonetheless determined by all decisive actions bearing the stamp of a more or less violent selfempowerment. And although they always mask this fact through evocation of individual claims to justice, this only means that in the symbolic vacuum of the dramatic world, even claims to justice face each other in a contingent manner-that is by means of violence.

If we consider Hebbel's drama as an experiment unfolding from start to finish in an interim condition and with the stipulation that the symbolic order be put aside, then the complex motifs of exchange, circulation, and gift-bestowal themselves take on a more precise contour. I have already suggested that in antiquity the Gyges legend offered ground for reflection on the relation between political rule 
and a money-based economy. Hebbel's adaptation of the tale plays on a double sounding board: the same problem half-mythologically cloaked by the antique authors is ferociously topical in his own time, stamped by both the crisis facing absolutist monarchies after 1848 and the expansion of capitalism. Kandaules's failed initiative for reform can, in fact, readily be spelled out along lines offered by Hebbel's contemporary political circumstances-put crudely, as an effort to build a bridge between divine right and the mass market. ${ }^{27}$

But the drama presents no successful change from traditional corporative monarchism to such stabilizing forms of rule, forms harmonizing with modern market regulation and its mechanisms of acknowledgment. It offers no conclusive recoding for its decoding. For whatever is negotiated and bargained, whatever changes place until finally no one and nothing is where it was, the actual organizing currency of the exchange relationships remains undefined. What general scale of values would allow the non-exchangeable to be reckoned against the exchangeable-old roots against wealth, a magic ring against sword and woman, "spouse's law" (Gyges 4.1478) against triumphing rivalry, finally, regicide against the loan of a secret peek? What forms the common denominator for all the alignments and arrangements born out of the moment, emerging as the social flip-side of the material transactions?

In order to respond adequately to these questions-to define adequately the basic problem at work here-we need to take up another new thread. One way of gaining an overview of the fantastic confusion of Hebbel's drama is by formalizing its disparate elements. And the capacity for formalization at work in Niklas Luhmann's system theory can here prove productive. With recourse to Luhmann, we can

${ }^{27}$ See Claudia Pilling citing Hans-Ulrich Wehler, Deutsche Gesellschaftsgeschichte (Munich: C.H. Beck, 1987). Tying Kandaules's "revolution from above" to political circumstances in the second half of the nineteenth century, she observes: "All of this thus means that the new state is meant to be worldly; its identity has to be grounded beyond the idea of ordo, hence as a nation - and the king is the first patriot. 'Base inviolability' thus can be interpreted as divine right, and the new meant to replace it as individual accomplishment. This is precisely the sort of state that, in Germany following the failed 1848 revolution, one might well have imagined even as a conservative reformer ..." (153). On the drama's political interpretability see also Birgit Fenner, Friedrich Hebbel zwischen Hegel und Freud (Stuttgart: Klett-Cotta, 1979) 109. 
separate the dramatic personae's diverse material and immaterial exchanges into three categories: first, power; second, money and property; third, love. For Luhmann, what these quantities have in common is that they serve as symbolically generalized communication media, by which he means "semantic facilities that allow inherently improbable forms of communication to succeed nevertheless." 28 He ties these facilities to one of society's functional systems: power with the political, money and property with the economic; love's system-reference is, however, manifestly more difficult to define. ${ }^{29}$

According to system theory's historical model, the threshold to modern society is characterized by a transition to functional differentiation. Functional systems differentiate themselves by developing an inherent rationality immunizing them against external influences. Luhmann describes this process as the closing of a system. The political system, for instance, processes material solely according to the differential determinant possession of power/loss of power, and the economic system consists of a series of sales and investment decisions that in turn attract other decisions of this sort. The fully formed functional systems only have a relation to the rest of the world to the extent that they are differentiated from it. Luhmann justifies this argument by indicating that systems simply cannot operate and consequently cannot observe (which means make distinctions) beyond the range of their code. He uses a series of terms in various phases of his work to define the mechanism through which the systems are nevertheless integrated into a comprehensive societal system-context: contact, irritation, dependence-context, synchrony, structural coupling, polycontexturality, and others as well.

Importantly, within system theory the realm between the systems remains unmarked as a matter of principle, belonging as it does to the environment about which, strictly speaking, nothing can be said. In this manner, Luhmann's theory follows up on the process of societal rationalization within modernity, described by Claus Offe as a

\footnotetext{
${ }^{28}$ Niklas Luhmann, Liebe als Passion. Zur Codierung von Intimität, 5th ed. (Frankfurt am Main: Suhrkamp, 1984) 21.

${ }^{24}$ See the tabular overview in Jan Künzler, Medien und Gesellschaft. Die Medienkonzepte von Talcott Parsons, Jürgen Habermas und Niklas Luhmann (Stuttgart: F. Enke, 1989) 100. Under "love," rubric "function-system," we find "family, intimate relations." We may doubt that this represents a system such as economy, law, and so forth. In this context I cannot address the question of the extent to which Luhmann's early concept of symbolically generalizable communication media can be harmonized with his more recent theory of auto-poetic functional systems.
} 
sum of uncoordinated partial modernizations, at the expense of a rationality of the society in its entirety. ${ }^{30}$ In doing so, the theory represents not only industrial modernism's operational blindness visà-vis ecology, but also the blind spot of systemic evolution in general in that systems are structurally incapable of reflecting on their own initial or marginal conditions. ${ }^{31}$

Let us now pause to juxtapose the results of our reading of Hebbel's drama with twentieth-century sociological theory. A picture emerges here that can hardly involve more contrast, tragedy, and theory corresponding in one single aspect: both attempt to model the threshold to modernity, each thus being concerned with a transition from pre-history to history. In all other respects, the two are mutually contra-evident. In the play, what Luhmann calls "generalized communication media" in no way serves to make nodes of communication possible. On the contrary, within the protagonists' triangle, the alternating references to love, property, and power hinder rather than facilitate likely communicative connections. In Hebbel's fictional arrangement, King Kandaules would stand for the dissolution of the patterns of legitimation and exclusiveness at work in premodern hierarchal societal structures. Luhmann views these structures as replaced by the formation of autonomous functional realms, each operating with its own code. But the figures in Hebbel's royal court are drawn into a melee of transactions and ad hoc equivalencies that are disastrously laid out through all such tidy subdivisions. His drama-I have already stated this-does not tell of that "happy" modernism into which function-specific codifications are embedded; rather, it generates the inverse picture of a condition of normative and epistemological anomie.

One might, of course, trace this striking contrast back to the different natures of two sorts of text. In that case, one might grant imaginative literature a claim to insight but not, precisely, systematic insight. But I in any event would disagree, on the grounds that this would involve a sharp underestimation of fiction's capacity for insight

${ }^{30}$ See Claus Offe, "Die Utopie der Null-Option," Die Moderne: Kontinuitäten und Zäsuren, ed. Johannes Berger (Göttingen: O. Schwartz, 1986) 97-117.

${ }^{31}$ See Albrecht Koschorke, "Die Grenzen des Systems und die Rhetorik der Systemtheorie," Widerstände der Systemtheorie. Kulturtheoretische Analysen zum Werk von Niklas Luhmann, ed. Albrecht Koschorke and C. Vismann (Berlin: Akademie, 1999) 4960 and Albrecht Koschorke, "System. Die Ästhetik und das Anfangsproblem," Grenzwerte des Ästhetischen, ed. Robert Stockhammer (Frankfurt am Main: Suhrkamp, 2002) 14663. 
accompanied by a giving of too much credit to the systematicity of systems. Namely, there is an additional methodological reason for system theory only reluctantly making pronouncements about the zone of exchange between mutually differentiating functional realms: this is the zone where the borders of competence are drawn in the first place; since the "terms of trade" between economy, family, politics, law, art, and so forth still have to be established, systemspecific binary codifications are simply not yet applicable. One can only argue systemically after the functional orders that have to be described actually exist and are doing their regulatory work. In a certain way, then, system theory always already presumes what it desires to unfold evolutionarily. It cannot perceive the "miasma," the as yet directionless impulse of movement and as yet preliminary formation of rules, that surplus of energy beyond the form from which the individual functional rationalities distill themselves. ${ }^{92}$

I would now like to suggest designating this chaotic space of "between" or "before"-a space of constantly alternating coordinates within which various types of rationality make contact, intersect, mix, strengthen and struggle with each other-as culture. This would have two advantages. In the first place, it would create the possibility of a culturalization of system theory. In the second place, culture could then be conceptualized, in a very general manner, as the locus of origin for forms of systemic rationality, which would leave behind nostalgic or compensatory models defining culture as either the remainder left by rationalizing processes or simply a remedy against the damage they cause.

As a source for systemic codifications, culture is stamped with special semiological qualities. It is the stage upon which the difference unfolds between differentiation and the lack of differentiation, ${ }^{33}$ code and non-code. Put more dramatically, on this as-it-were pitched field, symbolic power struggles for the radius of validity of various rationalities are enacted-whether, say, specific conflicts are to be

\footnotetext{
${ }^{32}$ Albeit only as a citation and with great caution, the miasma concept is indebted to Cornelius Castoriadis, Gesellschaft als imaginäre Institution. Entwurf einer politischen Philosophie (Frankfurt am Main: Suhrkamp, 1990) 564. On the inherent problems of this concept, see Susanne Lüdemann, Metaphern der Gesellschaft (Munich: Fink, 2004) 47.

${ }^{33}$ Hegel discusses this as the original difference in the $\ddot{A}$ sthetik, in relation to the "symbolic art-form" that is open to formlessness. Georg Wilhelm Friedrich Hegel, "Vorlesungen über die Ästhetik I," Werke in zwanzig Bänden, ed. Helmut Reinicke, vol. 13 (Frankfurt am Main: Suhrkamp, 1983) 393.
} 
solved morally, legally, or politically, or how conspicuous mixed forms are to be treated. ${ }^{34}$ All of this takes place on the condition that a clear distinction between code and operation, the rules and the game is not yet possible. And this means that other, more variable descriptive forms are needed in order to catch sight of cultural improvisation at both the preparatory zone and the margins of systematic differentiation.

A dense narrative texture is laid across this pre-systemic threshold terrain; it is composed of motifs involving foundation, (de-)legitimation, colonialization, and the autonomization of spheres of social meaning. Now, all narratives obey certain rhetorical and linguistic rules whether or not they are literary in a narrow sense; literary theory thus has a natural competence to explore them. Inversely, "fantastical" literary texts thus receive a functional-historical locus to carry out their work of cultural semiology, strict schematisms being too unwieldy or one-dimensional to deal with the complexities such texts address and convey. This, then, is the locus where formalizable currents, having run back into a reservoir of informal linkages, reemerge from that reservoir once again.

A more exhaustive analysis of Hebbel's play would involve a broad examination of the political semantics at work in Germany in the period following 1848 . In the present context, we must be content

\footnotetext{
${ }^{94}$ One can make good use of Luhmann's historical derivation of the concept of culture, while at the same time objecting to models he introduced of "culture" as memory and as a storage space for various semantic options. (He introduced such models without at all hiding his low opinion of a term considered far too broad.) According to Niklas Luhmann, "Kultur als historischer Begriff," Gesellschaftsstruktur und Semantik. Studien zur Wissenssoziologie der modernen Gesellschaft, vol. 4 (Frankfurt am Main: Suhrkamp, 1975) 31-54, here 32, the concept "first received its modern stamp in the second half of the eighteenth century" as a category for second-order observations that need to cope with conceptual relativity and are looking for a mode of comparability. Soon after in the same discussion, Luhmann observes:

In the 18 th century, this interest in comparison expands and deepens against the model of a concept of culture drawn from the usual circle of comparative themes and set down for itself... Even religions can now be compared as cultural manifestations and thus be treated as having equal status either explicitly (Lessing's Nathan) or implicitly. ... But the old extreme relevance of religion is relativized in the process. It is not, however, replaced by the concept of culture in a kind of semantic revolution. Rather, culture is placed on a meta-level that remains indeterminate regarding questions of primacy, and that must remain compatible with the variance of both "values," as one now puts it, and priorities. (36)
} 
with the observation that in deciding to elaborate dramatically on a tale seemingly far-removed from contemporary events, Hebbel placed his analysis of power in a central position, and this in two respects. On the one hand, the dissolution of an obsolete stratificational order can be portrayed with special plasticity at a royal court-the pinnacle of such an order. In hereditary monarchies at least, the king's body is in itself a highly hybrid construction: it is a symbolic body representing the embodiment of the polity, and it is at the same time a sexual body responsible for the dynasty's physical continuation. It is thus tautly located between institutional abstraction and its concrete, fleshly nature. When King Kandaules, like a Louis Philippe removed to antiquity, expresses the desire to descend from his throne and become a citizen among citizens, a friend among friends, a man among men, it is then that he becomes entangled in a very modern way in the paradoxical legacy of the monarchic state's construction.

On the other hand, Hebbel endowed the figure of the woman located between the two men with more personal contours, thus expanding their antagonism far beyond his models and into a triangular relationship. For a narrative, the triangle is the simplest form for generating sheerly unfathomable complexity from a limited repertoire of personal connections. In addition, it tends to favor the family schema, playing its part in disturbing the dividing line between public and private spaces that was so important for the nineteenth century's political imaginary. It is no coincidence that Hebbel left hints inviting us to decipher the play as an Oedipal scenario, ${ }^{35}$ displacing the struggle for power from the royal bed to the bourgeois bedchamber.

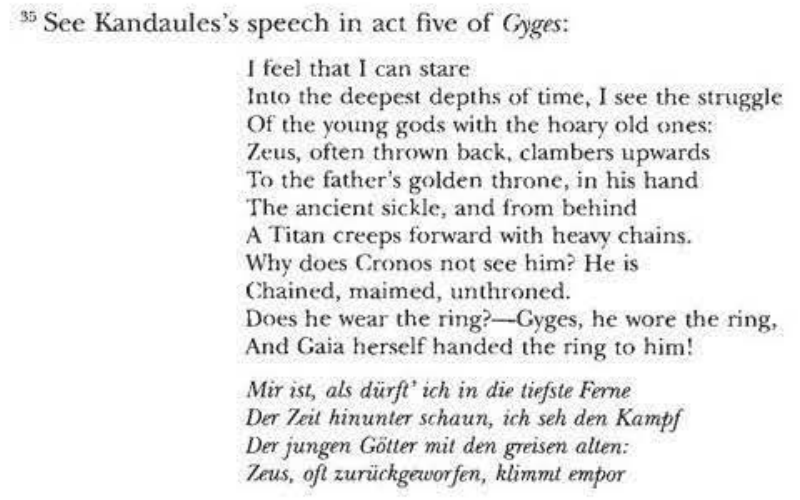


The drama thus operates here in the catchment area of a "tertiary logic." ${ }^{36}$ And this is connected not only to the rivalry schema but also to the special character of the "figure of the Third." This figure serves as an instrument for formalizing and systematizing social relationsan instrument that at the same time drives forth the a-systemic and non-dissolving, the remainder, hence the question of culture, out from itself.

Universität Konstanz

Translated by Joel Golb

Zum goldnen Stuhl des Vaters, in der Hand Die grause Sichel, und von hinten schleicht Sich ein Titan heran mit schweren Ketten.

Warum erblickt ihn Kronos nicht? Er wird Gefesselt, wird verstümmelt, wird gestürzt. Trägt der den Ring? - Gyges, er trug den Ring, Und Gäa selbst hat ihm den Ring gereicht!

See Andrea Stumpf's observations connected with this passage (123).

${ }^{36}$ See the research program of the University of Constance graduate seminar, established in 2003: Die Figur des Dritten, U Konstanz, Constance: <http://www.unikonstanz.de/figur3/>. 